\title{
Obituary/Obitukario Ricardo Andreazze (1964-2018)
}

Victor Py-Daniel $\bowtie$

Ex-Orientador e amigo do saudoso Ricardo Andreazze.

\section{EntomoBrasilis 11 (2): 154-155 (2018)}

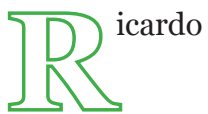

Chegou junto porque as pesquisa eram com indígenas.

Era um biólogo com coração de etnólogo.

Detalhista nas suas pesquisas, mas expansivo nas relações.

Tenso pelas suas experiências de vida, tendo um "algo" para resolver... lutou muito para identificar o que era... e entre os Yanomami teve a oportunidade de reconhecer que a relação paterna tinha que ser refeita. Refez.

Pessoa que soube ser conselheiro, dizendo, por exemplo: "você confia muito nas maquinas, se referindo ao uso de automóveis".

Um coração sem limites quando se tratava de apoiar os Yanomami.

Parecia uma grande garça branca, quando em festividades de dança, em conjunto com os Yanomami, pois tinha uma estatura grande em relação a eles.

Confiava muito no SER HUMANO, até que este ser lhe mostrase o quanto também pode ser falho... aí ficava experto... mas sempre com carinho.

Gostava de caminhar na floresta e sempre estava atento para as relações na Natureza, olhando com delicadeza para os insetos, coleópteros e lepidópteros.

Um ótimo companheiro para beber, tocar viola, e andar pela floresta (andava muito e bem).

Desconfiado SEMPRE de presentes.

Gostava muito de uma argumentação prolongada, principalmente quando acompanhada da cerveja. Se tivesse que escolher entre trabalhar no laboratório e na floresta, a floresta era a sua casa.

Paulista com coração indígena.

Victor Py-Daniel

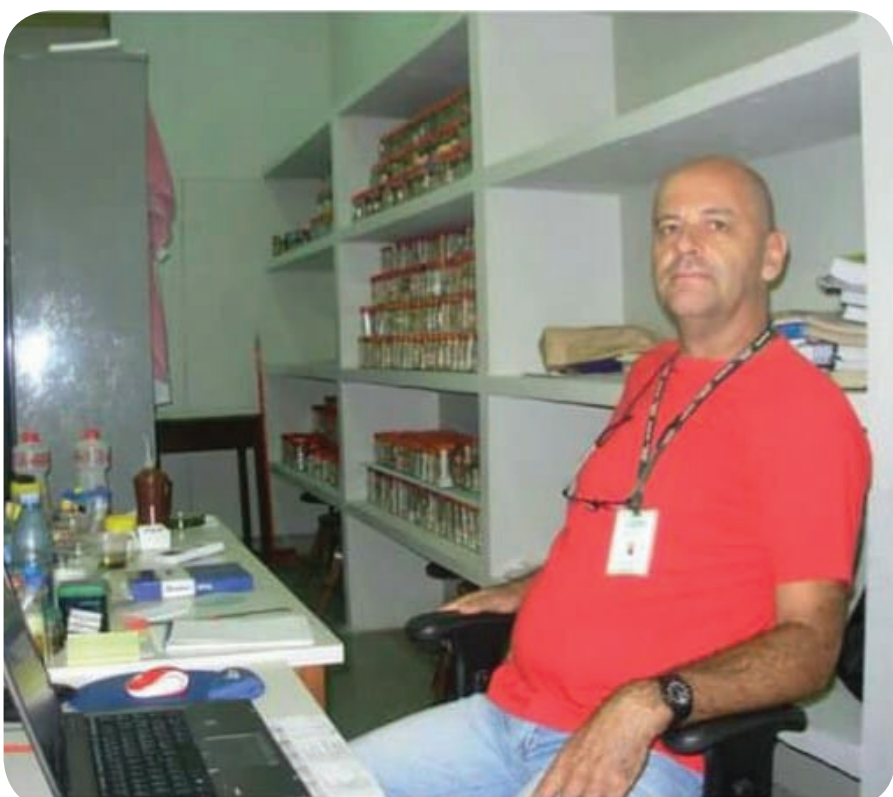

Prof. Dr. Ricardo Andreazze, foto extraída do Facebook.

\section{NOTA DA ENTOMOBRASILIS}

Ricardo foi um incansável entusiasta da EntomoBrasilis, atuando por anos como Editor-Assistente e jamais se negou a editorar um trabalho ou avaliar. Sempre com muita presteza e eficiência entregava as tarefas que lhe eram solicitadas em tempo recorde.

A EntomoBrasilis não perde um Editor-Assistente, perde um amigo, um entusiasta um ídolo. E assim muito consternados, nós da equipe prestamos essa singela, mas sincera homenagem a nosso amigo, que nos deixou precocemente, pouco antes de completar seus 54 anos.

Agradecemos ao Prof. Dr. Herbet Tadeu de Almeida Andrade da Universidade Federal do Rio Grande do Norte, colega de trabalho e amigo do nosso saudoso Ricardo, pela ajuda em nos fornecer um texto que pudesse homenageá-lo, indo até o Dr. Victor Py-

\section{Edited by:}

William Costa Rodrigues

\section{Article History:}

Received: 3o.viii.2018

Accepted: 31. viii. 2018

\section{Corresponding author:}

Victor Py-Daniel

乃katukina@gmail.com

(3) No ORCID record
Funding agencies:

Without funding declared 
Daniel, ex-orientador, que brilhantemente, nos brinda com um texto poético e leve, assim como outrora fora Ricardo.

Obrigado Herbet e Victor, nós da EntomoBrasilis, sabemos como deve ter sido doloroso para vocês a perda, mas sabemos como devem estar gratificados por poder prestar essa homenagem.

À família de Ricardo, nós da EntomoBrasilis deixamos uma fraterno abraço e desde que recebemos a notícias nos solidarizamos com a perda.

Por fim, eu William Costa Rodrigues, Editor-Chefe, infelizmente, não conheci Ricardo pessoalmente, mas criamos um forte laço de amizade, dentro do ambiente de trabalho da Revista e tenham certeza, que me dói quando penso, que não mais poderei enviar uma mensagem ao amigo, curtir e comentar suas publicações na rede social, ver novas fotos, inclusive de seu talento como músico, mas ao mesmo tempo tenho a convicção, que devemos ficar com as melhores lembranças desse SER HUMANO MARAVILHOSO que foi Ricardo Andreazze.

Ricardo foi professor nas disciplinas de Parasitologia Humana, Entomologia Geral, Entomologia Médica, fundador da disciplina de Entomologia de Campo e chefiou o Departamento de Microbiologia e Parasitologia do Centro de Biociências da UFRN, por duas gestões, com muito apego, responsabilidade e equanimidade.

\section{Suggestion citation:}

Py-Daniel, V., 2018. Ricardo Andreazze (1964-2018). EntomoBrasilis, 11 (2): 154-155.

Available on: doi:10.12741/ebrasilis.v11i2.810
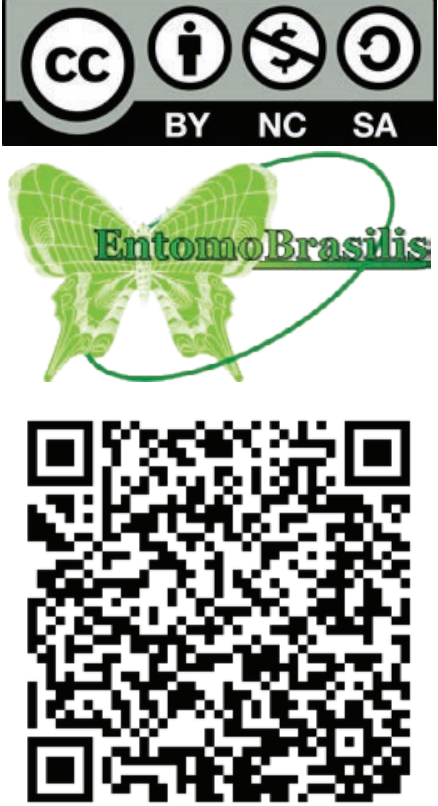